\title{
Deliberation in Citizenship Education: How the School Context Contributes to the Development of an Open Classroom Climate
}

\author{
Maurissen Lies, Claes Ellen, Barber Carolyn \\ Accepted for publication in Social Psychology of Education
}

Abstract - Schools are expected to contribute to preparing students for engaged citizenship. Research shows that open classroom discussions on political issues have a positive effect on political attitudes and behaviour. However, a deeper understanding of why students perceive their classrooms as open for discussion is missing. The purpose of this study is to examine how deliberative democratic theory can be used to explain such perceptions. We argue that the openness of the discussion climate is positively affected on the one hand by a context of good student-teacher relations characterised by fairness and respect and on the other hand, by the level of collective efficacy, which is the perception of responsiveness of the school towards student demands. Using multilevel analyses on the European data of the International Civic and Citizenship Education Study (ICCS 2009), we find that these predictors are significant at the student level and the school level. This means that both the individual experience of a student as well as the average school's score on good student-teacher relations and collective efficacy affect how students perceive the discussion climate. Our findings, based on high-quality survey data from 22 countries, are a significant contribution to clarifying the underlying mechanism leading to an open classroom climate. As such discussions have proven to be an effective way to stimulate political engagement, we conclude that a school context characterised by fairness and responsiveness, should not be overlooked by schools and policy.

Keywords - Citizenship Education; Open Classroom Climate; Student-teacher

Relations; Collective Efficacy; Deliberative Democracy; International Civic and Citizenship Education Study (ICCS) 2009; 


\section{Introduction}

In a democratic society different socialization agents can shape young people's civic values and attitudes. Alongside parents, peers and organizations, schools contribute to this process of attitude and value formation (Gimpel, Lay, and Schuknecht 2003; Flanagan 2013; Neundorf, Smets, and Garcia-Albacete 2013; Langton and Jennings 1968; Eidhof et al. 2017; Osler and Starkey 2006; Reichert 2016). They do so through civics courses, extra-curricular activities, service-learning and a democratic school climate (Dijkstra et al. 2015; McFarland and Starmanns 2009; Flanagan et al. 2014; Claes, Hooghe, and Marien 2012; Kahne and Sporte 2008; Quintelier 2010). From previous research we know that an open classroom climate for discussion relates especially positively to important civic values such as political trust and tolerance (Campbell 2008; Persson 2015; Torney-Purta et al. 2001). What lacks in this research is a deeper understanding of how individuals perceive their classroom climate as open for discussion. This paper will examine how characteristics of secondary schools in Europe relate to the way that students perceive their classrooms as places where they can openly discuss public matters.

We draw on a central component of deliberative democratic theory (Bächtiger and Steiner 2005; Dryzek 2009; Fishkin and Luskin 2005; Gutmann and Thompson 2004) that places discussion at the centre of democracy. Authors such as Hess (2009) and Parker (2003) draw parallels between deliberative theory and the school environment when they argue that classroom discussions on controversial political issues stimulate democratic capacity building amongst adolescents. If the development of civic attitudes benefits from discussions, we need to know more about how to stimulate such a climate. Deliberative democratic theory argues that an environment accessible to all participants based on equality and respect for different opinions displayed is crucial for deliberation to be considered successful (Gutmann and Thompson 2004). For adolescents to engage in a deliberation, they must feel respected and fairly treated by their teachers. In addition, responsiveness towards citizen demands is considered to be a pivotal feature of deliberative democracy (Chambers 2013; Habermas 2006). Students need to feel that their voices are heard and valued.

Based on literature and research, we expect a respectful relation between students and teachers on the one hand and a school which is responsive towards student demands on the other hand to stimulate an open discussion climate. We argue that these school characteristics serve as necessary conditions for schools to be a suitable playground for practicing deliberative skills. When a school environment is perceived as disrespectful and unwelcoming to student 
involvement, individual students will refrain from expressing their opinions. Specifically, we measure if good student-teacher relationships and responsiveness towards student demands affect the openness of the discussion climate using multilevel analyses on the European sample of the IEA ICCS 2009 data (Schulz, Ainley, Fraillon, Kerr and Losito 2010). The individual perception of discussion climate is the dependent variable in our analysis as we are interested in the effects of the school context on such perceptions. We start by explaining theories of political socialization in schools and how elements of deliberative democracy can be applied in a school environment. Subsequently, we describe the data and method used for analyses, followed by a presentation of the results and a critical discussion of our main findings.

\section{Why schools matter}

Schools are expected to contribute to preparing students for engaged citizenship. Besides designated civics courses (Niemi and Junn 1998), more attention has been given to other forms of educating students in becoming citizens in the past decades. The creation of a democratic environment for learning and interacting with peers and teachers is considered to be very important in stimulating adolescents' civic engagement (Flanagan et al. 2007; Torney-Purta et al. 2001; Parker 2003; Parker and Hess 2001; Hess 2009; Quintelier 2010). Schools can be seen as polities where students live together and shape their ideas and identity as citizens (Flanagan 2013). Schools gather students of different backgrounds regarding social class, religion or ideological background. Adolescents live together in this public arena, outside the family environment, and encounter a diverse set of values and opinions. These circumstances make schools promising sites for experiencing democracy.

In his seminal work Education and Democracy, Dewey (1916) argues that any experience, however trivial it may seem, can have long lasting effects when the consequences of the experience itself are endured and recognized. The aim is not primarily cognitive, but can be found in the value of the experience itself. Therefore, if one wants to stimulate the creation of democratic values, democracy itself should be experienced. When strengthening the connection between young people and democracy, it hardly seems appropriate to look at the distant relationships students have with elected representatives (Flanagan, Cumsille, Gill and Gallay 2007). For adolescents the strength of local community ties (Dewey 1916), such as the school, is more relevant. Learning how to be a citizen, how to express your opinion, and how to gain confidence in a fair process of coming to a decision takes time and practice (Flanagan et al. 2007). Within the school environment, confidence in the system, as well as in students' 
own capacities, can grow through recurrent successful experiences. This continuous effect makes schools a very fertile soil for democratic capacity building (Hess 2009; Parker 2003).

\section{Deliberation in democratic schools}

Deliberative democratic theory puts discussion at the centre of democracy (Dryzek 2000; Mansbridge 2003). It is a normative theory as it claims to be a more democratic way of dealing with the pluralism of our modern democracies. The focus lies not merely on aggregation of citizens' individual preferences through elections, but on the mechanisms of discussion and public opinion formation in a more continuous manner (Dryzek 2000; Habermas 1984). This talk-centred view of democracy underlines the importance of accountability of elected authorities towards their citizens and the communicative process of forming an opinion (Chambers 2013). The theory has undergone a transformation growing past a theoretical or institutional ideal (Cohen 2007; Thompson 2008) into a broadly applicable democratic theory. A definition which fits the use of deliberation in this paper is given by Chambers:

"Deliberation is debate and discussion aimed at producing reasonable, well informed opinions in which participants are willing to revise preferences in light of discussion, new information, and claims made by fellow participants. Although consensus need not to be the ultimate aim of deliberation, and participants are expected to pursue their interests, an overarching interest in the legitimacy of outcomes (understood as justification to all affected) ideally characterizes deliberation." (Chambers, 2003, p. 309).

Deliberation is a discussion open to all participants, in which any argumentation should be presented in a comprehensible manner (e.g. excluding purely religious reasoning). Participants are encouraged to grow past self-interested thinking and to show mutual respect for different opinions displayed. The discussants can reflect on their preferences in a non-coercive manner leading to a better understanding of alternate viewpoints (Gutmann and Thompson 2004; Dryzek 2000; Chambers 2013; Jacobs, Cook, and Delli Carpini 2009).

The deliberative turn also extended possible sites where deliberation is deemed useful (Ercan and Dryzek 2015). Whereas authors such as Rawls (1993) focus on official sites for deliberation in existing institutions, e.g. parliament and courts, others scholars locate deliberation in more unofficial sites, such as social movements, protest organizations and the media (Ercan and Dryzek 2015), as well as interactions between two citizens (Gundersen 2000), or what Mansbridge (1999) refers to as everyday talk. Also schools are considered to be 
suitable sites for deliberation (Gutmann 1995; Hess 2009; Parker 2003). The added value of deliberation in schools lies in its potential of fostering active citizenship. If the educational system wants to stimulate engagement among adolescents, students need to be taught how to become democratic citizens without neglecting the diversity of today's society (Enslin, Pendlebury and Tjiattas 2001). Social diversity and tolerance towards this diversity is considered to be a basic virtue for citizenship education (Gutmann 1995; Hess and McAvoy 2015; Macedo 1995; Parker 2003; Rawls 1993) following the reasoning that mutual respect cannot be taught without exposing students to different opinions about public matters. Students can reason with each other about a matter that exceeds any purely individualistic interest, listen to competing viewpoints and consider each other as equals (Hess and McAvoy 2015). Students not only learn more about the subjects at hand, but also acquire the skill of engaging in a highquality public talk (Hess 2009). As schools bring together a variety of students (e.g. gender, religion, social background, intelligence), adolescents run into a more diverse set of opinions on any given subject than they would in their home environment (Parker 2003). They learn how to form and express an opinion and listen respectfully to others with whom they might disagree (Avery, Levy and Simmons 2013). Such reasoning teaches respect for reasonable disagreement (Gutmann 1995), as students learn to agree to disagree (Mutz 2006).

When we talk about schools as places where democracy can be experienced and practiced, we refer to a democratic school climate. Schools are communities where students interact with each other and learn more about their own positions on public matters (Levine 2006). Young peoples' democratic attitudes are influenced by everyday experiences with democracy, such as decision-making processes in the classroom and whether students' feel that their opinions are valued by others (Flanagan 2013; Nieuwelink, Dekker, Geijsel and ten Dam 2016). But how can schools improve their democratic outlook? First, we stress the importance of students' sense of efficacy, a perception of responsiveness towards student demands, to reach the full potential of these discussions. Second, we look at the relationship between students and teachers, as the latter have the power to allow discussion within the classroom and are in a position to decide whether students' efforts are appreciated or overlooked.

\subsection{The role of collective efficacy}

Political efficacy is a fundamental political attitude (Almond and Verba 1989; Hahn 1998; Sohl and Arensmeier 2015). It is the confidence in one's ability to make a difference (Hahn 1998; Pasek, Feldman, Romer and Jamieson 2008). Scholars consider political efficacy as pivotal for 
civic engagement, as a sufficient level of efficacy is required for people to actually participate and become civically engaged (Delli Carpini 2000). When someone does not feel able to contribute to a decision-making process or competent to deal with civic issues, he or she is likely to avoid any involvement (Pasek et al. 2008). This is supported by Bandura's work on social cognitive theory when he argues that people need to believe that they can produce desired effects by their own actions; otherwise they have little incentive to act (Bandura 2000).

The sense of political efficacy develops early in life. However, adolescents' understanding of responsiveness of political authorities may not be shaped directly by the political system, as this is a very distant relationship. To understand the development of feelings of efficacy, we need to look at proximate environments of adolescents in which they interact (Bandura 1997). Adolescents have many opportunities to try to influence adults within the institutional settings they have to deal with, most notably the educational system. These feelings of efficacy can serve as a foundation for feelings of efficacy towards larger communities and political arenas. Young people learn how to be a citizen through opportunities and conditions created within their own communities (Bandura 1997; Flanagan et al. 2007; Godfrey and Grayman 2014).

Many efforts that people pursue require individuals to work together and speak with a collective voice to initiate change. The strength of a group, whether it is a family, an organization or a community, relies on the idea that acting together increases the possibility of improving lives for the better. The belief that collective action generates power and brings the group to the desired outcome is referred to as collective efficacy (Bandura 1997). This is no different for pupils in a school environment. Schools are places where interactions with nonfamilial adults regularly occur, thus creating many opportunities for working together and perceiving fair or unfair treatment in this proximate environment (Flanagan et al. 2007; Sohl and Arensmeier 2014). Torney-Purta et al. (2007) refer to schools as communities of practice, where students learn how to interact and work together with others and develop a foundation for citizenship. If young people want to influence adults, in this case the teachers, they ought to work together to accomplish change for the better. Consequently, we look at students' perceptions of collective efficacy (Bandura 1997; Bandura 2002) to see how they influence the openness of classroom discussions. In their study on youth political consciousness, a concept combining critical reflection, socio-political efficacy and critical action, Godfrey and Grayman (2014) found a similar relationship between the feeling of collective efficacy (or what they refer to as 'school efficacy') and the level of discussion within a classroom. Students need to feel that their voices are heard, and that when they cooperate on a matter of their concern, the 
school will be receptive to listen to their demands. This feeling of responsiveness of the school towards their demands is captured by the concept of value of student participation (Schulz et al. 2010). Based on the literature and previous studies, we expect to find a positive relation between students' perception of value of participation and the discussion climate, as students who feel their opinions are appreciated and who believe in the power of collective action will be more inclined to openly express their opinion.

\subsection{The role of teachers}

When looking at students interacting with adults in schools, one cannot work around the important authority in the proximate environment of adolescents: the teachers. They can (or cannot) create the discussion opportunities and decide to either value or disregards students' efforts. A considerable amount of research has been done on the relation between students' feelings of well-being in school on the one hand and their motivation and performance level on the other hand. The way teachers use their authority, how they interact with students, and how standards of respect, fairness and equal treatment are set reflects deeply on students' feeling of belonging to the school community. Research indicates that a good relationship is positively correlated with students' engagement and motivation to perform well (Roeser, Midgley, and Urdan 1996; Sullivan and Transue 1999; Flanagan et al. 2007; Jennings and Greenberg 2009; Eccles and Roeser 2011; Wentzel and Wigfield 2007; Wentzel 1997; Resh and Sabbagh 2017). Midgley et al. (1989) found a strong relation between the perception of teachers' support and the motivation to learn. The better the school environment was perceived, the more value was given to the subject taught. A positive student-teacher relation, characterized by trust, mutual respect and feelings of belonging, are positively related to engagement and motivation to learn (Roeser, Midgley and Urdan 1996). Following the idea of pedagogical caring, the feeling that teachers care about their students, is a predictor for motivational outcomes at school. Students will feel more inclined to engage in any classroom activity when they feel cared for (Wentzel 1997).

If democracy is learning by doing (Dewey 1916), democratic standards should be set in the school environment and put into practice by the teachers. Deliberative theorists emphasize that the context in which deliberation takes place needs to be characterized by fairness and respect. This requirement is as well valid in a school environment (Avery et al. 2013; Hess and McAvoy 2015; Hess 2009; Parker and Hess 2001; Parker 2003). Values such as respect, fair treatment and tolerance should be present and acted upon in the school environment, as they create a true 
democratic climate for learning and practicing how to become an engaged citizen (Flanagan et al. 2007). The student-teacher relationship is therefore perceived as an essential component of a democratic climate where deliberation can be practiced.

In sum, this paper will measure the effect of a respectful student-teacher relationship and students' collective efficacy on the openness of the discussion climate. When a positive effect can be found, a deeper understanding of the process behind classroom discussions will be achieved. As the lack of clarity about the underlying mechanism is often indicated as a gap in existing studies (Campbell 2008; Persson 2015; Torney-Purta et al. 2001), this paper will advance citizenship education research by taking a step back and looking at the discussion climate as a dependent variable. We address the question if the context in which discussions take place affects the perceived openness of the discussion climate by students. Our research question for analysis is therefore: do the student-teacher relationships and the value of student participation affect students' perceptions of an open discussion climate in secondary schools?

\section{Data and Sample}

Data for this analysis come from the 2009 International Civic and Citizenship Education Study (ICCS 2009), conducted by the International Association for the Evaluation of Educational Achievement (IEA). This international study of students enrolled in the eighth grade (approximately 14 year olds: Schulz et al. 2010) questioned students, teachers and principals about the context in which students learn about citizenship, including classroom climate, knowledge, attitudes and behaviour. This study uses data from 22 European countries ${ }^{1}$ containing 67,695 students from 3212 schools. The participating students were selected through a two-stage cluster sample. The schools were sampled within each country using probability proportional to size, measured by the number of students attending a school, to ensure a representative sample. Within each sampled school, an intact class was randomly selected. All students within that class participated (Schulz, Ainley and Fraillon 2009). The amount of missing data is low in our dataset, ranging from $1.1 \%$ for gender to $2.1 \%$ for immigration background. Cases with missing values were excluded from our analysis, using

\footnotetext{
1 The participating countries are Austria, Belgium (Flanders), Bulgaria, Cyprus, Czech Republic, Denmark, England, Estonia, Finland, Greece, Ireland, Italy, Latvia, Lithuania, Malta, Norway, Poland, Slovakia, Slovenia, Spain, Sweden and Switzerland. The Netherlands were excluded as the sample requirements were not met. Luxemburg and Liechtenstein are not included as the sample size was very small, in accordance with the advice given by the ICCS 2009 user guide (Brese et al. 2009).
} 
listwise deletion. ${ }^{2}$ To take possible violations of the independence assumption resulting from this sampling design into account, three-level multilevel analyses (students in schools in countries) with design weights ${ }^{3}$ are used (Brese, Jung, Mirazchiyski, Schulz and Zuehlke 2009; Hox 2010).

The student-teacher relation and the value of student participation are included in our model on the individual level, as well as on the school level. Both values are relevant for our research question. On the one hand, we want to measure the effect of how students feel about the relationship with their teachers on the perception of openness of the classroom climate. On the other hand, we want to include the effect of the classroom mean score of student-teacher relations on the individual perception of the discussion climate, as being part of a group which evaluates this relation as good might have an effect on your personal experience in classroom discussions, independent of your own personal evaluation of this relationship. By including the average score of the participating students in each school, the effect of the overall school context is taken into account, in addition to the individual perceptions of the students.

When both the individual as well as the aggregate scores are used in the same model, they are highly correlated, as the score of an individual student contributes to the school mean. To resolve this problem, the individual scores of the students are centred around their group mean, meaning that for each students the deviation from the school mean is used. On the second level, the school average is centred around the grand mean, being the mean value of the entire sample of schools. The value of students on the individual level is therefore uncorrelated with the aggregated score, as the first represents the deviation for the school mean, whereas the latter is the deviation of the grand mean: the average score of all 3212 schools involved in the sample (Hox 2010; Paccagnella 2006; Raudenbush and Bryk 2002). All other variables used in the analyses are centred around their grand means.

\footnotetext{
${ }^{2}$ Descriptive statistics, including missing values, are listed in appendix.

3 The sampling design used is a stratified two-stage cluster design, with schools sampled using probability proportional to size. This design calls for sampling weights to compensate for disproportional selection probabilities of a school or a student, as well as a non-response adjustment. When applying multilevel analysis to the ICCS 2009 data, a 'within-school student weight' and a 'school weight' should be used on the first and the second level of analysis respectively, as described by the ICCS 2009 User Guide for the International Database (Brese et al., 2009). All participating countries received a weight of 1, to make sure all are accounted for equally in the analyses.
} 


\section{Measures $^{4}$}

\subsection{Classroom climate}

A deliberative classroom setting is one where open discussions on matters of political or social interest take place in a respectful and inclusive manner. Previous research indicates that having regular classroom discussions leads to higher political knowledge, political interest, political trust, perceived future participation, appreciation of conflict and intention to vote (Barber, Sweetwood and King 2015; Campbell 2008; Claes, Hooghe and Marien 2012; Dassonneville et al. 2012; Gniewosz and Noack 2008; Godfrey and Grayman 2014; Hahn 1998; Torney-Purta et al. 2001). However, students and teachers seem to have a rather limited conception of what a good discussion is and do not often engage in a qualitative, in-depth exchange of views. When several students shortly state their opinion without real student-student interaction, the students and their teachers presume they were involved a discussion (Avery, Levy and Simmons 2013; Torney-Purta et al. 2001). The amount of 'cross-cutting' political discussions, meaning that people interact with people having a different opinion than their own (Mutz, 2006), is thought to be considerably low. Research shows that only $23 \%$ of American adults actually engage in such discussions. But when such discussions do take place, even without meeting all conditions of a good deliberative practice, they are still positively related to the above mentioned civic outcomes (Mutz 2006; Hess 2009). This led Avery et al. (2013) to conclude that even minimalist discussions stimulate the development of civic attitudes and skills.

We measure the discussion climate within the school using the Openness of Discussion Climate item response theory (IRT) scale which captures 'the extent to which students experience their classrooms as places to investigate issues and explore their opinions and those of their peers' (Torney-Purta et al. 2001: 138) and was used by many other scholars in previous studies on classroom discussions (e.g. Campbell 2008; Dassonneville et al. 2012; Gainous and Martens 2012; Lenzi et al. 2014; Persson 2015). The scale measures more than the quantity of discussion opportunities during classes, by asking students how often they are encouraged to express their opinion, if several sides of an issue are explained respectfully by the teacher and if they are encouraged to discuss issues with people having a different opinion than their own. In addition, one of the items asks how often students bring up current political events for discussion, which requires them to feel sufficiently comfortable to raise issues they feel worthy of being

\footnotetext{
${ }^{4}$ All items used to construct the scales can be found in appendix, alongside the descriptive statistics.
} 
discussed. Therefore, the scale goes beyond measuring the quantity of discussions, but touches as well upon the quality. The scale consists of six items on a four-point scale ('never', 'rarely', 'sometimes', or 'often'). The internal consistency of the scale is 0.751 (Cronbach's alpha) for the sample of 22 European countries. Higher values represent a higher level of perceived openness. Scale scores are set to an international average of 50 and a standard deviation of 10 for the weighted dataset (as described in the Technical Report of ICCS 2009: Schulz et al. 2009, p.163)..$^{5}$

\subsection{Value of student participation}

Similarly to the study of Godfrey and Grayman (2014) on fostering critical consciousness, we measure collective efficacy through students' perception of how their participation efforts can lead to change and the extent to which they feel valued within the school environment. The scale consists of five items on a four-point scale (ranging from 'strongly agree' to 'strongly disagree'). A higher score resembles a higher extent of agreement with the statements about the value of participation (Schulz, Ainley and Fraillon 2009). The items question students about their agreements with statements such as 'lots of positive changes can happen if students work together', 'students participation in how schools are run can make schools better' and 'organizing groups of students to express their opinions could help solve problems in schools'. These questions are asked to students about their perception of the school in general. The reliability of the scale is 0.784 (Cronbach's alpha) and the correlation with the dependent variable is $0.235 .^{6}$

We hypothesize that a higher score on the perceived value of student participation leads to a higher score on the openness of the classroom climate, derived from the idea that if students feel their efforts are valued and that working together leads to positive changes, the school becomes a small-scale democratic society which is responsive to the demands of its citizens, in this case the students. We argue that this practice will stimulate the openness of discussions in the classroom.

\footnotetext{
5 The international sample of 38 countries participating the 2009 IEA International Civic and Citizenship Education Study has an average of 50 and a standard deviation of 10 for each scale. This is also the case for the other ICCS scales used in the analyses: 'value of student participation' and 'student-teacher relationship'.

${ }^{6}$ Looking at the countries separately, the correlations between the independent and dependent variables fall within a reasonable range and could not be considered problematic. Also multicollinearity was tested (VIF: 1.018).
} 


\subsection{Student-teacher relationship}

Deliberation only reaches its full potential when embedded in a fair and respectful environment (Avery, Levy and Simmons 2013). Participants need to feel that they can share their opinion freely and will be respected by others, even when disagreement amongst participants is displayed. Therefore, a good relationship between students and teachers is imperative when creating a constructive and supportive atmosphere in which an open classroom climate can exist. We measure perceptions of student-teacher relationships with a scale of five items asking students about the relationships with teachers: e.g. 'most of my teachers treat me fairly', 'students get along well with most teachers' and 'most of my teachers really listen to what I have to say'. The scale's internal consistency is 0.729 (Cronbach's alpha) and the correlation with the dependent variable is $0.301 .^{7}$ We hypothesize that the student-teacher relationship has a positive effect on open classroom climate, as fairness and respect are considered as prerequisites for good deliberative environments. The better the perceived relationship with the adults in school, the more the students are likely to express their opinions, even if they disagree with the teacher or with other students.

\subsection{Background characteristics}

We also include several demographic characteristics of the students as control variables, when previous research indicated that an influence on classroom climate could be identified. We expect a positive relation between classroom climate and gender, as girls are more likely to report a higher level of openness of classroom climate than boys (Barber et al. 2015; Campbell 2007).

Immigration background is included, as ethnic background is often claimed to be related to different forms of engagement (e.g. Geijsel et al. 2012; Kahne and Sporte 2008). Campbell found in his study on American high school students that racially mixed classes led to less discussions (Campbell 2007). Students with migration background include first and second generation migrants, using students' self-report.

Socioeconomic background has proved to be highly relevant when analysing data on political attitudes and competences (Campbell 2008; Castillo et al. 2015; Geijsel et al. 2012). We use

\footnotetext{
${ }^{7}$ Also for this variable we looked at the correlation with the dependent variable for each country separately. The scores fall within a reasonable range and cannot be considered problematic. Multicollinearity was as well tested (VIF: 1.019).
} 
home literacy as a proxy variable for the social background of the family as it reflects the general intellectual environment in the home (Barber, Sweetwood and King 2015; Campbell 2007; Claes, Hooghe and Marien 2012; Manganelli, Lucidi and Alivernini 2015; Persson 2012; Torney-Purta et al. 2001).

Previous research reports a positive link between open classroom climate and the level of political knowledge of the students (Campbell 2007, 2008; Gainous and Martens 2012; Persson 2015). We therefore include a score for political knowledge in our model as a control variable. ${ }^{8}$

\subsection{Discussions outside the classroom}

In our analyses, we also take the discussion habits of the students outside the classroom into account as a control variable. Learning how to form and express an opinion and to listen respectfully to a counterpart are skills that can be acquired in many different settings. In particular, the home environment and discussions with friends on political or socially relevant topics can serve as practice for engaging in a political talk. This way, discussions become a part of students' everyday discourse. They will feel more inclined to engage in any discussion, also within the school environment (Youniss 2011). We expect a positive relation between political discussions with family and friends, and the perception of open classroom climate. Political discussions with friends and family are included in a four-point-scale, ranging from 'never' to 'almost daily'.

\section{[insert Table 1]}

\section{Results}

All models in our analyses are analysed using three-level hierarchical linear modelling with HLM 7 statistical software, estimated via maximum likelihood (Raudenbush, Bryk, Cheong, Congdon and du Toit, 2011). The fully unconditional model in Table 1 shows that $9.7 \%$ of the variance in classroom climate perceptions exists between schools and $4.7 \%$ between countries, which supports our choice for multilevel analysis. In the first model, both student-teacher relations and the value of participation measured on student level have a significant and positive effect on the perceptions of classroom climate ( 0.246 and 0.153 respectively, $p<.001)$, which is in accordance with our hypotheses. When students perceive the relation with the

\footnotetext{
879 items of the cognitive test were used to derive a civic knowledge scale, see ICCS 2009 Technical Report (Schulz et al. 2009).
} 
teachers as respectful and fair, they think of the classroom climate as more open compared to students who perceive an unfair environment. The same goes for the value of participation: students with a higher sense of collective efficacy report a more open discussion climate.

In the second model, we include the demographic background characteristics, measured at student level. Gender proves to have a significant effect, as is the case in most studies that include classroom climate. Girls perceive the classroom climate to be more open than their male peers $(2.089, p<.001)$. More political knowledge is positively associated with classroom climate. Also, students with many books at home tend to perceive a more open climate for discussion. However, when the measures for discussion outside the classroom are taken into account in model three, the coefficient for socio-economic background is no longer significant. Practice of discussion elsewhere is a predictor of the openness of the classroom discussion. ( 0.708 for discussions within the family and 0.843 for discussions with friends, $p<.001)$. For immigration background, we were not able to show a significant relation with our dependent variable. Neither set of control variables drastically changes the effects of our two predictors of central interest.

In a fourth model, student-teacher relations and value of participation are found to have significant slope variation, indicating that the relation between these variables and classroom climate perceptions differs depending on the school one is attending. We expect that the individual perception of both the student-teacher relations and their feelings of collective efficacy have an effect on the perception of the discussion climate. Therefore, we include the school average score of both variables in our fifth model and in a second step see how both effects relate to each other by testing a cross-level interaction. Both aggregates have a positive effect on classroom discussions: a higher school mean perception of the value of participation and of the student-teacher relation goes together with a higher score on classroom climate ( 0.245 and 0.363 respectively, $\mathrm{p}<.001)$. The individual effects remain stable in strength.

Model six in Table 2 includes the cross-level interactions between the scores on both levels of the two independent variables. The interaction effect for the individual and aggregate measure of the student-teacher relationships is significant and negative. This means that for students who are in a class with a good average score, the individual perception of a student matters less. In other words, the effect of the individual perception of the relationship with teachers on classroom discussions is larger for students who are in a school with a lower average score on student-teacher relations. The effect of the individual perception is smaller when the average score for student-teacher relations is higher. To make our estimation of the variance 
components more accurate, we allow the slope of the country level to vary as well in model seven. We now find a similar interaction effect for the value of participation. When the school average score of the feeling of collective efficacy is high, the effect of the individual perception of the student is smaller.

Finally, we take a closer look at the gender effect in classroom discussions. As previous studies indicated and is confirmed in our analyses, girls perceive the classroom climate in general to be more open than boys. We see in model eight that the influence of gender differs according to the school one is attending. Model nine shows that the difference between boys and girls becomes smaller when the average score for the value of student participation is higher. The interaction effect for gender and the student-teacher relations is not significant.

\section{[insert Table 2]}

\section{Discussion}

Students engaging in a discussion on public matters while showing respect for different opinions will have a positive effect on the democratic capacity-building of schools. A democratic school climate makes students experience democracy within the polity of the school. According to Dewey (1916), these experiences should be endured and frequently practiced to gain results in the desired civic outcomes, such as democratic attitudes or skills. The inherent diversity present in a school environment should be used as an asset (Parker 2003) to fuel discussions on matters that are of interest to all. As many researchers showed the advantages of such discussions, the importance within educational practices as such is not questioned (e.g. Campbell 2008; Persson 2015; Castillo et al. 2015; Pasek et al. 2008; TorneyPurta et al. 2001; Dassonneville et al. 2012). But how such a climate is nourished within a school is less known. In this paper, we took a step back and looked at perceptions of the discussion climate as the dependent variable, as it is students' sense of being in a classroom where they are encouraged to share their opinion that will affect civic attitudes (Hess 2009; Manganelli et al. 2015; Torney-Purta et al. 2001).

We are interested in the contextual predictors within a school of such perceptions to see how we can improve and strengthen the existence of a discussion climate within our educational system. According to deliberative democratic theory, responsiveness and mutual respect are essential when stimulating high level discussions. Both elements can be present in a school environment when students feel their efforts are valued, when they have the feeling that their 
voices are head, as well as when there is a general feeling of mutual respect between students and teachers.

Our results confirm that the teacher plays a crucial role in creating a democratic school climate. As previous research of Wentzel (1997) indicated: the feeling that teachers care for students motivates them to perform well. Our results show that this is also the case when maintaining an open discussion climate. Students who feel respected and get along well with their teachers think of their schools as places where they are encouraged to express their opinion and discuss matters with people who have a different view than their own. We found similar results for collective efficacy: when students feel that working together can initiate positive changes within the school environment, they perceive the classroom climate as more open. Our findings show that a context of fairness, respect and responsiveness towards student demands stimulate discussions in schools. These results were found in 22 European countries using high-quality survey data. We therefore argue that the insights given in this paper contribute substantially to a better understanding of the underlying mechanism leading to open classroom discussions. Within a democratic school climate, students can develop skills to deliberate and practice how to become engaged citizens. As this is an important goal of citizenship education, the stimulation of a democratic school climate through the school context should not be overlooked by schools and policy.

A limitation of our analysis is the measurement of discussions in a classroom. The construct measures the perceived discussion climate: to what extent do students feel that their classroom is a place where they can have an open exchange of views on political or social issues. It does not cover the full quality of the discussions, nor does it give full disclosure concerning the actual occurrence of discussions. Future research through observations or experiments could complement our research by giving more information about what is being said during the discussion and if these discussions are high quality discussions resembling deliberations, or mere classroom talks. A second limitation is linked to the cross-sectional data of ICCS, which does not allow us to make any statements on the causal direction of the effects found through multilevel analyses. Future research should look into the direction of the effect, by using data and methods which allow making such claims.

If we want to maintain an engaged citizenry, we need adolescents to learn what it means to be part of a democracy. If engaging in a deliberative discussion produces learning (Gundersen 2000), students will become better informed and display more tolerance towards the diversity inherent to our society (Hess 2009; Parker 2003). Schools are promising sites for experiencing 
deliberation. When embedded in a fair, respectful and responsive environment, students will be able to explore their position within this democratic polity and practice the art of deliberation. 
Table 1. Results for open classroom climate using hierarchical linear modelling

\begin{tabular}{|c|c|c|c|c|c|c|}
\hline & $\begin{array}{c}\text { Null } \\
\text { Model }\end{array}$ & Model I & Model II & Model III & Model IV & Model V \\
\hline Intercept & $50.320 * * *$ & $50.318 * * *$ & $50.480 * * *$ & $50.461 * * *$ & $50.460 * * *$ & $50.382 * * *$ \\
\hline \multicolumn{7}{|l|}{ Student level variables (L1) } \\
\hline student-teacher relation & & $0.246(0.004)^{* * *}$ & $0.237(0.004)^{* * *}$ & $0.231(0.004)^{* * *}$ & $0.224(0.005)^{* * *}$ & $0.225(0.013)^{* * *}$ \\
\hline value of participation & & $0.153(0.004)^{* * *}$ & $0.114(0.004)^{* * *}$ & $0.104(0.004)^{* * *}$ & $0.105(0.005)^{* * *}$ & $0.107(0.005)^{* * *}$ \\
\hline gender $($ girl $=1)$ & & & $2.089(0.083)^{* * *}$ & $2.187(0.082)^{* * *}$ & $2.170(0.082)^{* * *}$ & $2.149(0.081)^{* * *}$ \\
\hline immigration $($ yes $=1)$ & & & $0.315(0.158)^{*}$ & $0.092(0.157)$ & $0.096(0.156)$ & $0.096(0.154)$ \\
\hline home literature & & & $0.163(0.033)^{* * *}$ & $0.052(0.033)$ & $0.057(0.033)$ & $0.063(0.033)$ \\
\hline political knowledge & & & $0.015(0.001)^{* * *}$ & $0.013(0.001)^{* * *}$ & $0.013(0.001)^{* * *}$ & $0.012(0.001)^{* * *}$ \\
\hline discussion family & & & & $0.709(0.049)^{* * *}$ & $0.702(0.048)^{* * *}$ & $0.684(0.048)^{* * *}$ \\
\hline discussion friends & & & & $0.843(0.058)^{* * *}$ & $0.817(0.057)^{* * *}$ & $0.796(0.057)^{* * *}$ \\
\hline \multicolumn{7}{|l|}{ School level variables (L2) } \\
\hline student-teacher relation & & & & & & $0.363(0.019)^{* * *}$ \\
\hline value of participation & & & & & & $0.245(0.022)^{* * *}$ \\
\hline Student level variance & 80.201 & 71.818 & 69.502 & 68.513 & 65.237 & 65.225 \\
\hline School level variance & 9.155 & 9.670 & 7.850 & 7.368 & 7.589 & 4.705 \\
\hline slope student-teacher relation & & & & & 0.021 & 0.021 \\
\hline slope value of participation & & & & & 0.015 & 0.015 \\
\hline Country level variance & 4.361 & 4.352 & 3.507 & 3.475 & 3.612 & 3.959 \\
\hline ICC school level & 0.097 & 0.112 & 0.097 & 0.093 & 0.099 & 0.064 \\
\hline ICC country level & 0.047 & 0.051 & 0.043 & 0.044 & 0.047 & 0.054 \\
\hline Deviance & 493007 & 485915 & 483289 & 482210 & 481487 & 480498 \\
\hline
\end{tabular}

Source data: ICCS 2009.

Note: Entries are coefficient estimates and standard errors (in parentheses) of a multilevel linear regression using HLM 7 (maximum likelihood estimation). The models include 67695 individuals at first level, 3212 schools at second level and 22 countries at third level. The appropriate weights were used to compensate for disproportional selection probabilities at student and school level. All variables in italic are entered grand mean centred, variables in bold italic are entered group mean centred. Significance levels: $*<0.05 ; * *<0.01 ; * * *<0.001$. 
Table 2. Results for open classroom climate: interaction effects

\begin{tabular}{|c|c|c|c|c|c|c|}
\hline & \\
\hline & Null Model (table 1) & Model V (table 1) & Model VI & Model VII & Model VIII & Model IX \\
\hline Intercept & $50.320 * * *$ & $50.382 * * *$ & $50.381 * * *$ & $50.381 * * *$ & $50.387 * * *$ & $50.396 * * *$ \\
\hline \multicolumn{7}{|l|}{ Student level variables (L1) } \\
\hline student-teacher relation & & $0.225(0.013)^{* * *}$ & $0.227(0.005)^{* * *}$ & $0.223(0.014)^{* * *}$ & $0.223(0.015)^{* * *}$ & $0.223(0.015)^{* * *}$ \\
\hline value of participation & & $0.107(0.005)^{* * *}$ & $0.108(0.005)^{* * *}$ & $0.108(0.008)^{* * *}$ & $0.108(0.008)^{* * *}$ & $0.108(0.008)^{* * *}$ \\
\hline gender $($ girl $=1)$ & & $2.149(0.081)^{* * *}$ & $2.142(0.081)^{* * *}$ & $2.142(0.081)^{* * *}$ & $2.146(0.089)^{* * *}$ & $2.142(0.088)^{* * *}$ \\
\hline immigration $($ yes $=1)$ & & $0.096(0.154)$ & $0.093(0.154)$ & $0.086(0.154)$ & $0.086(0.153)$ & $0.087(0.153)$ \\
\hline home literature & & $0.063(0.033)$ & $0.066(0.033)$ & $0.066(0.033)$ & $0.063(0.032)$ & $0.063(0.032)$ \\
\hline political knowledge & & $0.012(0.001)^{* * *}$ & $0.012(0.001)^{* * *}$ & $0.012(0.001)^{* * *}$ & $0.012(0.001)^{* * *}$ & $0.012(0.000)^{* * *}$ \\
\hline discussion family & & $0.684(0.048)^{* * *}$ & $0.683(0.048)^{* * *}$ & $0.681(0.048)^{* * *}$ & $0.680(0.048)^{* * *}$ & $0.680(0.048)^{* * *}$ \\
\hline discussion friends & & $0.796(0.057) * * *$ & $0.798(0.057)^{* * *}$ & $0.795(0.056)^{* * *}$ & $0.798(0.056)^{* * *}$ & $0.799(0.056)^{* * *}$ \\
\hline \multicolumn{7}{|l|}{ School level variables (L2) } \\
\hline student-teacher relation & & $0.363(0.019)^{* * *}$ & $0.365(0.019)^{* * *}$ & $0.365(0.018)^{* * *}$ & $0.365(0.019)$ & $0.364(0.018)^{* * *}$ \\
\hline value of participation & & $0.245(0.022)^{* * *}$ & $0.243(0.022)^{* * *}$ & $0.241(0.022)^{* * *}$ & $0.237(0.022)$ & $0.240(0.022)^{* * *}$ \\
\hline \multicolumn{7}{|l|}{ Interactions } \\
\hline student-teacher relation L1xL2 & & & $-0.006(0.001)^{* * *}$ & $-0.006(0.001)^{* * *}$ & $-0.006(0.001)^{* * *}$ & $-0.006(0.001)^{* * *}$ \\
\hline value of participation L $1 x L 2$ & & & $-0.002(0.001)$ & $-0.004(0.001)^{* * *}$ & $-0.004(0.001)^{* * *}$ & $-0.004(0.001)^{* * *}$ \\
\hline gender x student-teacher rel. L2 & & & & & & $-0.001(0.023)$ \\
\hline gender $x$ value of part. $L 2$ & & & & & & $-0.080(0.027)^{* *}$ \\
\hline Student level variance & 80.201 & 65.225 & 65.236 & 65.212 & 64.619 & 64.626 \\
\hline School level variance & 9.155 & 4.705 & 4.705 & 4.705 & 4.675 & 4.676 \\
\hline slope student-teacher relation & & 0.021 & 0.020 & 0.017 & 0.017 & 0.016 \\
\hline slope value of participation & & 0.015 & 0.015 & 0.015 & 0.015 & 0.015 \\
\hline slope gender & & & & & 2.421 & 2.341 \\
\hline Country level variance & 4.361 & 3.959 & 3.954 & 3.920 & 3.879 & 3.869 \\
\hline slope student-teacher relation & & & & 0.004 & 0.004 & 0.004 \\
\hline slope value of participation & & & & 0.001 & 0.001 & 0.001 \\
\hline ICC school level & 0.097 & 0.064 & 0.064 & 0.064 & 0.094 & 0.093 \\
\hline ICC country level & 0.047 & 0.054 & 0.035 & 0.053 & 0.051 & 0.051 \\
\hline Deviance & 493007 & 480498 & 480449 & 480295 & 480226 & 480210 \\
\hline
\end{tabular}

Source data: ICCS 2009.

Note: Entries are coefficient estimates and standard errors (in parentheses) of a multilevel linear regression using HLM 7 (maximum likelihood estimation). The models include 67695 individuals at first level, 3212 schools at second level and 22 countries at third level. The appropriate weights were used to compensate for disproportional selection probabilities at student and school level. All variables in italic are entered grand mean centred, variables in bold italic are entered group mean centred. Significance levels: $*<0.05 ; * *<0.01 ; * * *<0.001$. 


\section{Appendix}

\subsection{Descriptive statistics}

\begin{tabular}{lcccccc} 
& $\mathrm{n}$ & mean & $\mathrm{SD}$ & $\min$ & $\max$ & $\begin{array}{c}\% \\
\text { missing }\end{array}$ \\
\cline { 2 - 7 } open classroom climate & 67695 & 50.41 & 9.65 & 14.83 & 78.98 & 1.3 \\
student-teacher relation & 67695 & 48.85 & 9.60 & 17.62 & 73.53 & 1.2 \\
value of participation & 67695 & 49.36 & 9.76 & 15.18 & 69.83 & 1.4 \\
Gender & 67695 & 0.51 & 0.50 & 0.00 & 1.00 & 1.1 \\
immigration background & 67695 & 0.09 & 0.28 & 0.00 & 1.00 & 2.1 \\
home literature & 67695 & 2.49 & 1.32 & 0.00 & 5.00 & 1.2 \\
political knowledge & 67695 & 520.55 & 95.52 & 133.08 & 887.01 & 0.0 \\
political discussion family & 67695 & 1.78 & 0.96 & 1.00 & 4.00 & 1.3 \\
political discussion friends & 67695 & 1.49 & 0.78 & 1.00 & 4.00 & 1.4 \\
student teacher relation - school & 3212 & 48.95 & 4.11 & 33.07 & 64.96 & 0.0 \\
value of participation - school & 3212 & 49.15 & 3.49 & 36.05 & 60.78 & 0.0
\end{tabular}

\subsection{Variables}

Open classroom climate:

Q: When discussing political and social issues during regular lessons, how often do the following things happen? Response options: never - rarely - sometimes - often.

- Teachers encourage students to make up their own mind.

- Teachers encourage students to express their opinion.

- Students bring up current political events for discussion in class.

- Students express opinions in class even when their opinions are different from most of the other students.

- Teachers encourage students to discuss the issues with people having different opinions.

- Teachers present several sides of the issues when explaining them in class.

IRT-scale: international average of 50 - standard deviation of 10 for the weighted dataset.

Cronbach's alpha is 0.751 for the sample of 22 European countries (Schulz et al. 2009).

Student-teacher relations:

Q: how much do you agree or disagree with the following statements about you and your school? Response options: strongly agree - agree - disagree - strongly disagree.

- Most of my teachers treat me fairly

- Students get along well with most teachers

- Most teachers are interested in students' wellbeing 
- Most of my teachers really listen to what I have to say

- If I need extra help, I will receive it from my teachers

IRT-scale: international average of 50 - standard deviation of 10 for the weighted dataset. Cronbach's alpha is 0.784 for the sample of 22 European countries (Schulz et al. 2009).

Value of student participation:

Q: How much do you agree or disagree with the following statements about student participation at school? Response options: strongly agree - agree - disagree - strongly disagree.

- Students participation in how schools are run can make schools better

- Lots of positive changes can happen in schools when students work together

- Organizing groups of students to express their opinions could help solve problems in schools

- All schools should have a school parliament

- Student can have more influence on what happens in schools of they act together rather than alone

IRT-scale: international average of 50 - standard deviation of 10 for the weighted dataset. Cronbach's alpha is 0.729 for the sample of 22 European countries (Schulz et al. 2009).

Gender: Boys 0 - Girls 1

Immigration background: $=$ first or second generation migrants

Students without immigration background 0 - Students with immigration background 1

Political discussion with friends and with family:

Question asking how often students engage in a discussions about political or social issues. Response categories: never to hardly ever - monthly - weekly - daily or almost daily.

\section{Civic Knowledge}

Student civic knowledge scores are derived from 79 items in the cognitive test. The constructed achievement scale has an international mean of 500 and a standard deviation of 100 for the weighted dataset.

Home literacy

Question asking students about the number of books at home: 0 to 10 books (0) - 11 to 25 books (1) - 26 to 100 books (2) - 101 to 200 books (3) - 201 to 500 books (4) - more than 500 books (5). 


\section{References}

Almond, G., \& Verba, S. (1989). The Civic Culture: Political Attitudes and Democracy in Five Nations. London: Sage Publications.

Andersson, E. (2015). Situational political socialization: a normative approach to young people's adoption and acquisition of political preferences and skills. Journal of Youth Studies, 18(8), 967-983.

Avery, P. G., Levy, S. a., \& Simmons, A. M. M. (2013). Deliberating Controversial Public Issues As Part of Civic Education. The Social Studies, 104(3), 105-114.

Bächtiger, A., \& Steiner, J. (2005). Introduction. Acta Politica, 40(2), 153-168.

Bandura, A. (1997). Self-efficacy: The exercise of control. New York: Freeman.

Bandura, A. (2000). Exercise of human agency through collective efficacy. Current Direcstions in Psychological Science, 9(3), 75-78.

Bandura, A. (2002). Social cognitive theory in cultural context. Applied Psychology, 51(2), 269-290.

Barber, C., Sweetwood, S. O., \& King, M. (2015). Creating classroom-level measures of citizenship education climate. Learning Environments Research, 18(2), 197-216.

Brese, F., Jung, M., Mirazchiyski, P., Schulz, W., \& Zuehlke, O. (2009). ICCS 2009 User Guide for the International Database (second edi). Amsterdam: The IEA Secretariat.

Campbell, D. E. (2007). Sticking Together: Classroom Diversity and Civic Education. American Politics Research, 35(1), 57-78.

Campbell, D. E. (2008). Voice in the classroom: How an open classroom climate fosters political engagement among adolescents. Political Behavior, 30(4), 437-454.

Castillo, J. C., Miranda, D., Bonhomme, M., Cox, C., \& Bascopé, M. (2015). Mitigating the Political Participation Gap from the School: The Roles of Civic Knowledge and Classroom Climate. Journal of Youth Studies, 18(1), 16-35.

Chambers, S. (2013). Deliberation and Mass Democracy. In J. Parkinson \& J. Mansbridge (Eds.), Deliberative Systems (pp. 52-71). New York: Cambridge University Press.

Claes, E., Hooghe, M., \& Marien, S. (2012). School Experiences, Classroom Climate and Political Trust. A Two-Year Panel Study among Belgian Late Adolescents on the Impact of School Environment Characteristics on Political Trust. International Journal of Public Opinion Research, 24(2), 208-224.

Cohen, J. (2007). Deliberative Democracy. In S. W. Rosenberg (Ed.), Deliberation, Participation and Democracy: Can The People Govern? (pp. 219-236). New York: 
Palgrave Macmillan.

Dassonneville, R., Quintelier, E., Hooghe, M., \& Claes, E. (2012). The Relation Between Civic Education and Political Attitudes and Behavior: A Two-Year Panel Study Among Belgian Late Adolescents. Applied Developmental Science, 16(3), 140-150.

Delli Carpini, M. X. (2000). Youth, Civic Engagement, and the New Information Environment. Political Communication, 17(4), 341-349.

Dewey, J. (1916). Democracy and education: An introduction to the philosophy of education. New York: Macmillan.

Dijkstra, A. B., Geijsel, F., Ledoux, G., van der Veen, I., \& ten Dam, G. (2015). Effects of school quality, school citizenship policy, and student body composition on the acquisition of citizenship competences in the final year of primary education. School Effectiveness and School Improvement, 26(4), 524 - 553.

Dryzek, J. S. (2000). Deliberative Democracy and Beyond: Liberals, Critics, Contestations. Oxford: Oxford University Press.

Dryzek, J. S. (2009). Democratization as Deliberative Capacity Building. Comparative Political Studies, 42(11), 1379-1402.

Eccles, J. S., \& Roeser, R. W. (2011). Schools as developmental contexts during adolescence. Journal of Research on Adolescence, 21(1), 225-241.

Eidhof, B. B. F., ten Dam, G. T. M., Dijkstra, A. B., \& van de Werfhorst, H. G. (2017). Youth citizenship at the end of primary school: The role of language ability. Research Papers in Education, 32(2), 217-230.

Enslin, P., Pendlebury, S., \& Tjiattas, M. (2001). Deliberative democracy, diversity and the challenges of citizenship education. Journal of Philosophy of Education, 35(1), 115-130.

Ercan, S., \& Dryzek, J. (2015). The reach of deliberative democracy. Policy Studies, 36(3), $241-248$.

Fishkin, J., \& Luskin, R. (2005). Experimenting with a Democratic Ideal: Deliberative Polling and Public Opinion. Acta Politica, 40(3), 284-298.

Flanagan, C. (2013). Teenage Citizens: The Political Theories of the Young. Cambridge: Harvard University Press.

Flanagan, C. a., Cumsille, P., Gill, S., \& Gallay, L. S. (2007). School and community climates and civic commitments: Patterns for ethnic minority and majority students. Journal of Educational Psychology, 99(2), 421-431.

Flanagan, C., Kim, T., Collura, J., \& Kopish, M. (2014). Community service and adolescents' 
social capital. Journal of Research on Adolescence, 25(2), 295-309.

Gainous, J., \& Martens, A. (2012). The Effectiveness of Civic Education: Are "Good” Teachers Actually Good for “All” Students? American Politics Research, 40(2), 232-266.

Geijsel, F., Ledoux, G., Reumerman, R., \& ten Dam, G. (2012). Citizenship in young people’s daily lives: differences in citizenship competences of adolescents in the Netherlands. Journal of Youth Studies, 15(6), 711-729.

Gimpel, J., Lay, C., \& Schuknecht, J. (2003). Cultivating Democracy: Civic environments and political socialization in America. Washington, DC: Brookings Institutions.

Gniewosz, B., \& Noack, P. (2008). Classroom climate indicators and attitudes towards foreigners. Journal of Adolescence, 31(5), 609-624.

Godfrey, E., \& Grayman, J. K. (2014). Teaching Citizens: The Role of Open Classroom Climate in Fostering Critical Consciousness Among Youth. Journal of Youth and Adolescence, 43(11), 1801-1817.

Gundersen, A. (2000). The Socratic Citizen: a Theory of Deliberative Democracy. Lanham, Md.: Lexington Books.

Gutmann, A. (1995). Civic Education and Social Diversity. Ethics, 105(3), 557-579.

Gutmann, A., \& Thompson, D. (2004). Why deliberative democracy? Princeton: Pinceton University Press.

Habermas, J. (1984). The theory of communicative action vol. 1: reason and the rationalization of society. Boston: Beacon Press.

Habermas, J. (2006). Political Communication in Media Society: Does Democracy still enjoy an Epistemic Dimension? The Impact of Normative Theory on Empirical Research. Communication Theory, 16(4), 411-426.

Hahn, C. L. (1998). Becoming Political: Comparative Parspectives on Citizenship Education. Albany: State University of New York Press.

Hess, D. E. (2009). Controversy in the Classroom: The Democratic Power of Discussion. New York: Routledge.

Hess, D. E., \& McAvoy, P. (2015). The Political Classroom: Evidence and Ethics in Democratic Education. New York: Routledge.

Hox, J. (2010). Multilevel analysis: Techniques and Applications (second edi). New York: Routledge.

Jacobs, L. R., Cook, F. L., \& Delli Carpini, M. X. (2009). Talking Together: Public Deliberation and Political Participation in America. Chicago: The University of Chicago 
Press.

Jennings, P. A., \& Greenberg, M. T. (2009). The Prosocial Classroom: Teacher Social and Emotional Competence in Relation to Student and Classroom Outcomes. Review of Educational Research, 79(1), 491-525.

Kahne, J., \& Sporte, S. (2008). Developing Citizens: The Impact of Civic Learning Opportunities on Students' Commitment to Civic Participation. American Educational Research Journal, 45(3), 738-766.

Langton, K. P., \& Jennings, M. K. (1968). Political Socialization and the High School Civics Curriculum in the United States. American Political Science Review, 62(3), 852-867.

Lenzi, M., Vieno, A., Sharkey, J., Mayworm, A., Scacchi, L., Pastore, M., \& Santinello, M. (2014). How school can teach civic engagement besides civic education: The role of democratic school climate. American Journal of Community Psychology, 54(3-4), 25161.

Levine, P. (2006). The civic mission of schools. Knowledge Quest, 34(4), 18-21.

Macedo, S. (1995). Liberal Civic Education and Religious Fundamentalism: The Case of God v. John Rawls? Ethics, 105(3), 468.

Manganelli, S., Lucidi, F., \& Alivernini, F. (2015). Italian adolescents' civic engagement and open classroom climate: The mediating role of self-efficacy. Journal of Applied Developmental Psychology, 41, 8-18.

Mansbridge, J. (1999). Everyday Talk in the Deliberative System. In S. Macedo (Ed.), Deliberative Politics (pp. 211-239). Oxford: Oxford University Press.

Mansbridge, J. (2003). Rethinking Representation. Amercian Political Science Review, 97(4), $515-528$.

McFarland, D., \& Starmanns, C. (2009). Inside Student Government: The Variable Quality of High School Student Councils. Teachers College Record, 111(1), 27-54.

Midgley, C., Feldlaufer, H., \& Eccles, J. S. (1989). Student / Teacher Relations and Attitudes toward Mathematics before and after the Transition to Junior High School. Child Developement, 60(4), 981-992.

Mutz, D. (2006). Hearing the other side: Deliberative versus participatory democracy. Cambridge: Cambridge university press.

Neundorf, A., Smets, K., \& Garcia-Albacete, G. M. (2013). Homemade citizens: The development of political interest during adolescence and young adulthood. Acta Politica, $48(1), 92-116$. 
Niemi, R. G., \& Junn, J. (1998). Civic Education. What Makes Students Learn. New Haven: Yale University Press.

Nieuwelink, H., Dekker, P., Geijsel, F., \& ten Dam, G. (2016). "Democracy always comes first": adolescents' views on decision-making in everyday life and political democracy. Journal of Youth Studies, 19(7), 990-1006.

Osler, A., \& Starkey, H. (2006). Education for Democratic Citizenship: a review of research, policy and practice 1995-2005. Research Papers in Education, 21(4), 433-466.

Paccagnella, O. (2006). Centering or not centering in multilevel models? The role of the group mean and the assessment of group effects. Evaluation Review, 30(1), 66-85.

Parker, W. (2003). Teaching Democracy. Unity and Diversity in Public Life. New York: Teachers College Press.

Parker, W., \& Hess, D. (2001). Teaching with and for discussion. Teaching and Teacher Education, 17, 273-289.

Pasek, J., Feldman, L., Romer, D., \& Jamieson, K. H. (2008). Schools as Incubators of Democratic Participation: Building Long-Term Political Efficacy with Civic Education. Applied Developmental Science, 12(1), 26-37.

Persson, M. (2012). Does Type of Education Affect Political Participation? Results from a Panel Survey of Swedish Adolescents. Scandinavian Political Studies, 35(3), 198-221.

Persson, M. (2015). Classroom climate and political learning: Findings from a swedish panel study and comparative data. Political Psychology, 36(5), 587-601.

Quintelier, E. (2010). The effect of schools on political participation: a multilevel logistic analysis. Research Papers in Education, 25(2), 137-154.

Raudenbush, S. W., \& Bryk, A. S. (2002). Hierarchical linear models: applications and data analysis methods (Second Edi). Thousand Oaks: Sage Publications.

Raudenbush, S. W., Bryk, A. S., Cheong, Y. F., Congdon, R. T., \& du Toit, M. (2011). HLM7: Hierarchical Linear and Nonlinear Modeling. Lincolnwood: Scientific Software International.

Rawls, J. (1993). Political Liberalism. New York: Columbia University Press.

Reichert, F. (2016). Students' perceptions of good citizenship: a person-centred approach. Social Psychology of Education, 19(3), 661-693.

Resh, N., \& Sabbagh, C. (2017). Sense of justice in school and civic behavior. Social Psychology of Education, 20(2), 387-409.

Roeser, R. W., Midgley, C., \& Urdan, T. C. (1996). Perceptions of the school psychological 
environment and early adolescents' psychological and behavioral functioning in school: The mediating role of goals and belonging. Journal of Educational Psychology, 88(3), $408-422$.

Schulz, W., Ainley, J., \& Fraillon, J. (2011). ICCS 2009 Technical Report. Amsterdam: The IEA Secretariat.

Schulz, W., Ainley, J., Fraillon, J., Kerr, D., \& Losito, B. (2010). ICCS 2009 International Report: Civic knowledge, attitudes, and engagement among lower-secondary school students in 38 countries. Amsterdam: The IEA Secretariat.

Sohl, S., \& Arensmeier, C. (2015). The school's role in youths' political efficacy: can school provide a compensatory boost to students' political efficacy? Research Papers in Education, 30(2), 133-163.

Sullivan, J. L., \& Transue, J. E. (1999). The Psychological Underpinnings of Democracy: A Selective Review of Research on Political Tolerance, Interpersonal Trust, and Social Capital. Annual Review of Psychology, 50, 625-50.

ten Dam, G., \& Volman, M. (2004). Critical thinking as a citizenship competence: Teaching strategies. Learning and Instruction, 14(4), 359-379.

Thompson, D. (2008). Deliberative Democratic Theory and Empirical Political Science. Annual Review of Political Science, 11(1), 497-520.

Torney-Purta, J., Lehmann, R., Oswald, H., \& Schulz, W. (2001). Citizenship and Education in Twenty-eight Countries.

Wentzel, K. R. (1997). Student Motivation in Middle School: The Role of Perceived Pedagogical Caring. Journal of Educational Psychology, 89(3), 411-419.

Wentzel, K. R., \& Wigfield, A. (2007). Motivational Interventions That Work: Themes and Remaining Issues. Educational Psychologist, 42(4), 261-271.

Youniss, J. (2011). Civic Education: What Schools Can Do to Encourage Civic Identity and Action. Applied Developmental Science, 15(January 2015), 98-103. 